\title{
TIME MANAGEMENT: MENGGUNAKAN WAKTU SECARA EFEKTIF DAN EFISIEN
}

\author{
Antonius Atosökhi Gea \\ Character Building Development Center (CBDC), BINUS University \\ Jln. Kemanggisan Ilir III No. 45, Kemanggisan - Palmerah, Jakarta 11480 \\ antoniusgea@binus.edu
}

\begin{abstract}
Living in the midst of a changing business environment, which many people are burdened with more than one responsibilities, especially in a company with very high business activity and also in highly competitive industry, is imperative for the leaders of the company to be able to manage their time well in order to survive and be able to move in a sustainable manner. The concept of time management began during the industrial revolution and became a modern idea about doing things effectively and efficiently. Time management is one of the basic skills needed to be successful in life. The findings of various surveys indicated that time management enabled organizations or companies learn to survive in the face of competition and achieve a lot of success in business.
\end{abstract}

Keywords: effective, efficient, control functions, productivity, results

\begin{abstract}
ABSTRAK
Hidup di tengah-tengah suasana lingkungan bisnis yang terus berubah, ketika orang banyak dibebani lebih dari satu tanggung jawab, khususnya dalam perusahaan dengan aktivitas bisnis sangat tinggi dan juga dalam dunia industri yang sangat kompetitif, merupakan keharusan bagi para pimpinan perusahaan untuk mengelola waktu dengan baik agar bisa bertahan dan dapat melangkah secara berkelanjutan. Konsep mengenai time management dimulai pada masa revolusi industri dan menjadi gagasan modern perihal melakukan sesuatu secara efektif dan efisien. Time management merupakan salah satu keterampilan dasar yang dibutuhkan untuk dapat sukses dalam hidup. Temuan dari berbagai survei menunjukkan bahwa time management memampukan organisasi/perusahaan belajar bertahan hidup dalam menghadapi persaingan dan meraih banyak keberhasilan dalam bisnis.
\end{abstract}

Kata kunci: Efektif, efisien, fungsi kontrol, produktivitas, hasil 


\section{PENDAHULUAN}

Time management merupakan salah satu keterampilan penting kepemimpinan, bahkan merupakan salah satu kunci keberhasilan dalam menjalankan suatu bisnis. Kepemimpinan dalam organisasi, khususnya terkait masalah pengambilan keputusan tentang masa depan bisnis, sangat tergantung pada pihak tingkat manajemen. Untuk memastikan tentang benarnya suatu keputusan yang dibuat sangat tergantung pada time management. Artinya, dalam membuat suatu keputusan penting tentang masa depan bisnis, perihal pengelolaan waktu merupakan hal sangat penting. Keputusan manajemen bagaikan investasi, tujuannya adalah untuk mendapatkan hal paling baik dari sumber daya yang dimiliki, memberikan kepadanya nilai tambah serta mendapatkan keuntungan paling baik (Mitch, 2011).

Time management adalah tindakan dan proses perencanaan dan pelaksanaan kontrol sadar atas sejumlah waktu yang akan digunakan untuk aktivitas tertentu, khususnya untuk meningkatkan efektivitas, efisiensi, dan produktivitas. Time management membutuhkan sejumlah skill, alat, dan teknik yang digunakan dalam mengelola waktu untuk menyelesaikan suatu tugas atau proyek dengan jangka waktu yang sudah ditentukan. Time management adalah salah satu isu paling penting dalam bisnis modern, dengan waktu dilihat sebagai satu dari sumber daya utama untuk meraih sukses. Namun bagaimana seorang menggunakan waktu kerja secara produktif supaya bisa melakukan semua tugas dan tetap mendapatkan kekuatan untuk tugas-tugas berikutnya merupakan tantangan penting dalam diri seorang pimpinan proyek maupun dalam diri individu. Waktu adalah sumber daya yang pasti namun dengan mudah bisa berlalu tanpa bisa kembali untuk digunakan pada kesempatan berikutnya.

Seorang perlu belajar dan berlatih menyelamatkan waktu dan menggunakannya secara baik, efektif dan efisien. Time management yang efektif dapat membantu melakukan hal penting di setiap jam kerja. Di dalamnya setiap pribadi atau pimpinan dapat menggunakan waktunya dengan baik, mendelegasikan tugas, mengorganisasi pekerjaan, merencanakan waktu perlu dibuat pertemuan (rapat), melakukan rehabilitasi efektif atas mental dan fisik setelah melakukan pekerjaan berat dan mengalami tekanan berat. Ini merupakan beberapa tugas utama, yang dapat dilaksanakan dengan baik jika time management yang baik diterapkan.

\section{METODE}

Penelitian ini menggunakan library research. Library research merupakan suatu studi pustaka yang dilakukan dengan menggunakan sumber bacaan yang relevan dan tersedia, yang berkaitan dengan topik yang dibahas dalam penelitian. Buku atau artikel jurnal yang berkaitan dengan topik yang dibahas dijadikan sebagai sumber bacaan, untuk memahami dengan baik seputar time management beserta penerapannya dalam level pribadi maupun organisasi. Dari berbagai sumber bacaan yang digunakan itu penulis mengembangkan tulisan ilmiah ini, termasuk ikut memberi tanggapan atau komentar kritis yang disampaikan di berbagai bagian dari tulisan, khususnya pada bagian simpulan. 


\section{HASIL DAN PEMBAHASAN}

\section{Pengertian Time Management}

Time management adalah tentang perencanaan hari/waktu supaya bisa melakukan penggunaan paling baik atas waktu yang dimiliki. Konsep atau istilah mengenai time management berawal dari revolusi industri, yaitu ketika mulai ada perhatian tentang pengelolaan waktu secara efektif dan efisien untuk bisa mengontrol waktu yang dimiliki seseorang. Sejak Drucker (1966) mempopulerkannya, konsep time management ini telah secara luas diterima sebagai hal yang menyumbang pada efektivitas karyawan (Adebisi, 2013).

Time management adalah tindakan atau proses perencanaan dan pelaksanaan pantauan sadar atas sejumlah waktu yang digunakan untuk aktivitas khusus, terutama untuk meningkatkan efektivitas, efisiensi, dan produktivitas (Singh \& Jain, 2013). Atau seperti dikatakan Humes (dalam Adebisi, 2013), time management secara singkat dapat diartikan sebagai suatu seni mengatur, mengorganisasi, menjadwalkan, serta menganggarkan waktu seseorang untuk menghasilkan kerja lebih efektif dan produktif. Waktu adalah sumber daya berharga, tidak dapat diganti dan tidak dapat diubah. Maka dari itu, sangat perlu untuk menggunakan waku dengan bijaksana. Time management mencakup tindakan menata, menjadwal, mengorganisasi, dan mengalokasikan setiap waktu seseorang yang digunakan untuk menyelesaikan tugas-tugas hariannya.

König (2007) mendefinisikan management sebagai proses organisasi, yang meliputi perencanaan strategis, penataan, penetapan tujuan, pengelolaan sumber daya, pengembangan manusia dan aset keuangan yang dibutuhkan untuk meraih tujuan dan mengukur hasilnya. Sedangkan time management merupakan seni menata urusan bisnis dan pribadi seefektif dan seefisien mungkin, membuat semuanya terlaksana dengan baik, secepat mungkin, dan dengan penggunaan sumber daya (waktu, energi, uang dan manusia) sesedikit mungkin. Tujuan utama di balik semua usaha itu adalah untuk menghemat waktu lama yang diperlukan untuk pelaksanaan tugas atau pekerjaan. Dengan kata lain, itu adalah suatu seni menata, mengorganisasi, menjadwal, dan menganggarkan waktu yang tersedia untuk tujuan menghasilkan kerja lebih efektif dan produktif.

Menurut Kusashi (dalam Adebisi, 2013), menunda pengambilan suatu keputusan atau bersikap reaktif terhadap suatu problem dapat mengakibatkan biaya mahal yang harus ditanggung oleh bisnis. Maka diperlukan sekali untuk memastikan bahwa pimpinan tidak melakukan kesalahan, dengan menunda pemanfaatan waktu yang sangat berharga bagi perusahaan. Time management yang baik akan sangat membantu perusahaan lebih produktif, lebih kreatif, menghemat banyak uang, dan menghindari bekerja pada saat-saat yang sudah kritis, dan secara meyakinkan dapat meningkatkan kesempatan meraih keberhasilan dalam bisnis.

\section{Pentingnya Penerapan Time Management}

Masalah time management merupakan hal umum bagi banyak orang. Banyak orang mengakui dan merasakan tentang perlunya, tetapi dalam kenyataannya mereka tidak memerhatikan dan menerapkannya. Tentang mengapa time management menjadi masalah bagi manusia, baru sekarang ini mendapat perhatian para peneliti. Khususnya, para ekonom dan dan psikolog telah mengembangkan argumen teoretis tentang mengapa time management berat bagi banyak orang. Salah satunya karena kurangnya keterampilan dan keberanian dalam mengembangkan dan menerapkan time management dalam kehidupan (Fischer, 2001). Fischer (2001) juga mencatat temuan dari teori behavioral decision bahwa orang sering mengabaikan hasil besar di masa depan yang bisa didapatkan ketika menerapkan time management yang bagus. Artinya, pengembangan dan penerapan time management itu hasilnya tidak selalu kelihatan pada tahap awal penerapannya, namun setelahnya, 
dengan penerapan yang konsisten, hasilnya bisa sangat mengagumkan. Jika hasil di masa depan tidak dipikirkan dalam time management yang dibuat kini, orang bisa jadi akan menggunakan waktu mereka untuk hasil-hasil yang sesegera mungkin bisa didapatkan, yang biasanya lebih kecil dari hasil-hasil lainnya, yang didapatkan kemudian dalam waktu yang jauh ke depan. Dengan kata lain, orang lebih suka hal-hal yang mendesak tetapi tidak penting ketimbang hal-hal penting tetapi tidak mendesak.

Time management yang bagus sangat penting untuk mengatasi tekanan-tekanan dari dunia modern ini tanpa mengalami terlalu banyak stres. Time management yang bagus tidak berarti melakukan banyak pekerjaan, melainkan berfokus pada tugas setepatnya dan membuat perbedaan. Apakah di dalam pekerjaan atau di kehidupan secara keseluruhan, seorang harus belajar bagaimana mengelola waktu secara baik, yang akan membantu merasa lebih relaks, fokus, dan terkontrol. Menurut Donaldson (dalam Adebisi, 2013) "The aim of good time management is to achieve the lifestyle balance you want." Waktu yang bagus dalam pekerjaan berarti melakukan pekerjaan berkualitas tinggi, bukan terutama tinggi dalam hal kuantitas. Claessens, et al (2007) menemukan bahwa menggunakan teknik time management akan berhubungan langsung dengan kinerja dan kepuasan, serta dapat mengurangi kegalauan dan kecemasan.

\section{Hal Penting yang Diperhatikan dalam Perancangan Time Management}

Untuk mengelola waktu secara efektif, masing-masing harus memiliki gambaran yang jelas mengenai prinsip-prinsip serta nilai utama kehidupannya. Seorang butuh menginvestasikan sumber daya berharga dari waktu untuk hal yang sangat penting. Scott (dalam Adebisi, 2013) memperjelas bahwa satu tantangan mendasar time management yang efektif adalah memahami perbedaan antara "urgent" dan "important", "mendesak" dan "penting”. "Mendesak" sendiri tidak membuat tugas itu penting. Hal "penting” itu terkait dengan prinsip pribadi. Prioritas bisnis yang menentukan hal penting dari kerja. Dengan kejelasan misi dan tujuan pribadi, waktu dijadwalkan dengan tujuan definitif dalam hati.

Seorang juga perlu merumuskan apa yang dimaksud dengan time management baginya dan bagaimana itu berkaitan dengan pengelolaan hidupnya. Dalam melakukan hal ini, ada 3 hal penting dari kehidupan yang perlu diperhatikan dalam kaitannya dengan pengelolaan waktu dengan baik, yakni: pekerjaan, kehidupan keluarga (termasuk teman-teman) dan diri sendiri (Atkinson, 2009). Seorang perlu memikirkan dengan baik hal penting yang ingin dicapai dengan nyata: tentang tujuan yang ingin dicapai di tempat kerja, tentang tujuan yang ingin dicapai dengan keluarga, dan tentang tujuan yang berkaitan murni dengan diri sendiri.

Misalnya dalam suatu proyek, penerapan time management sangat diperlukan untuk mendukung terjadinya efisiensi bagi pengontrolan kemajuan yang dicapai, untuk menjadwal, dan menjalankan apa yang telah disepakati oleh beberapa pihak yang terlibat. Time management merupakan salah satu area utama perhatian pimpinan proyek beserta timnya. Dengan adanya time management berarti akan tersedia aturan dalam menjalankan dan memantau kemajuan suatu proyek dan pengambilan keputusan-keputusan penting terkait dengannya. Para profesional dari suatu proyek sekarang telah menyadari akan pentingnya hal ini.

Dalam suatu proyek, pimpinan proyek dan timnya berjuang keras untuk memenuhi dengan baik jadwal yang sudah dibuat untuk menyelesaikan tugas dengan kualitas yang baik. Sinkronisasi antara berbagai hal dan kepentingan dari beberapa pihak yang terlibat dalam suatu proyek merupakan hal sangat penting untuk diperhatikan. Yang dikatakan terlibat di sini tentu saja bukan hanya manusia, tetapi juga berbagai sumber daya lainnya, seperti bahan/materi yang diperlukan, dana, tempat, transportasi, perangkat komputer, perizinan, dan sarana lainnya serta waktu itu sendiri. Dalam tahap operasional, menjadwal pekerjaan, membuat kategorisasi jenis pekerjaan yang harus diselesaikan dalam waktu tertentu, menetapkan kualitas hasil yang diinginkan, dan lain-lain, merupakan sebagian dari hal-hal menarik sekaligus menantang dalam suatu proyek. 
Konsep dasar time management adalah penggunaan waktu secara efisien dalam merealisasikan pengerjaan suatu tugas. Para ahli percaya bahwa beberapa hal berikut penting dipertimbangkan dalam perancangan time management yang bagus. Pertama, memprioritaskan tugas-tugas penting, dan didasarkan atas sumber daya yang tersedia. Kedua, mengembangkan perencanaan dan menggunaan waktu yang tersedia dengan cara seefisien mungkin. Ketiga, terus memantau penyimpanganpenyimpangan dan gangguan yang terjadi yang mengganggu jalannya pekerjaan sesuai jadwal. Keempat, mengembangkan efisiensi dan mengurangi tekanan atas jadwal yang telah dibuat termasuk tekanan kepada para individu yang terlibat dalam proyek

Pimpinan suatu proyek idealnya harus memprioritaskan tugas-tugas pengerjaan proyek berdasarkan sumber daya dan tenaga manusia yang tersedia baginya. Mengembangkan perencanaan merupakan kunci sukses manajemen atas sumber daya yang tersedia. Sumber daya dan time management dapat secara efisien dikelola melalui jadwal yang diprogramkan dengan baik. Jadwal yang konstruktif akan memperlihatkan dengan jelas kapan suatu proyek dimulai dan kapan harus selesai. Dalam kurun waktu tersebut -antara mulai mengerjakan sampai pada penyelesaiannya- perlu disadari akan terjadi banyak tekanan yang akan mengganggu jadwal dan juga orang-orang yang terlibat di dalamnya. Memahami dengan baik kemampuan tim sebagai keseluruhan akan dapat membantu dalam membuat target yang dapat dicapai secara realistis (Kasturi \& Gransberg, 2002).

\section{Mendahulukan yang Utama}

Salah satu habit dari ketujuh habit yang dikembangkan oleh Covey (2004) sebagai kunci keberhasilan bagi manusia yang sangat efektif adalah tentang mendahulukan yang utama. Mendalami lebih lanjut apa yang disampaikan oleh Scott, di sini dibeberkan sedikit pandangan Covey tentang perbedaan antara penting dan mendesak. Kedua hal itu ("penting" dan "mendesak") membentuk 4 kuadran dengan ciri khas masing-masing. Kudran I berkaian dengan hal-hal penting dan juga mendesak; kuadran II berisi hal-hal penting tapi tidak mendesak; kuadran III berisi hal-hal tidak penting namun mendesak; dan kuadran IV berisi hal-hal tidak penting dan juga tidak mendesak (Covey, 2004). Ini sebuah konsep pengelolaan waktu manajemen generasi keempat, yang pada dasarnya fokus menggunakan waktu pada salah satu dari empat kondisi itu.

Hal-hal mendesak adalah hal-hal yang memerlukan perhatian segera, sekarang juga. Hal-hal mendesak ini bertindak terhadap seorang, yang membuatnya tergoda untuk tidak bisa melepaskannya, sehingga cenderung menggunakan banyak waktu untuk memenuhinya. Hal yang mendesak biasanya tampak jelas, ia mendesak dan menuntut tindakan; hal itu terjadi di “depan hidung”. Biasanya hal-hal mendesak ini bersifat menarik, mudah, menyenangkan untuk dikerjakan, hasilnya segera kelihatan. Akan tetapi, masalah-masalah mendesak ini bisa jadi sebenarnya tidaklah penting.

Sebaliknya, hal-hal penting, yang tampak masih jauh di depan mata, ada hubungan dengan hasil yang ditetapkan terkait dengan tujuan yang ingin dicapai, bahkan dengan nilai-nilai pribadi. Ia fokus pada pemeliharaan dan peningkatan hubungan pada pencapaian hasil, memelihara keseimbangan antara produk dan kemampuan produksi (P/KP). Ia tidak hanya senang dan puas dengan hasil (produk) tetapi juga lebih penting lagi adalah bagaimana agar kemampuan untuk memproduksi menjadi fokus perhatian utama. Hal-hal itu tergolong penting karena dia menunjang misi, nilai-nilai pribadi, sasaran prioritas penting diri. Untuk itu, hal utama yang mesti dimiliki adalah tujuan yang ingin dicapai, visi, misi, nilai-nilai pribadi. Hal-hal yang berkaitan dengan pencapaian atau perwujudan akan hal-hal itu dikategorikan sebagai penting. Seorang harus bertindak untuk menangkap peluang, untuk membuat segalanya terjadi. Jika ia tidak mempunyai gagasan yang jelas tentang apa yang penting, tentang hasil yang diinginkan dalam hidup, ia akan dengan mudah dialihkan untuk merespons hal-hal mendesak yang sudah ada di depan mata. Dengan cara seperti ini, hal-hal yang sesungguhnya penting menjadi terabaikan. 


\begin{tabular}{|c|c|c|}
\hline & Mendesak & Tidak mendesak \\
\hline Penting & $\begin{array}{l}\text { I } \\
\text { AKTIVITAS: } \\
\text { Krisis } \\
\text { Masalah yang mendesak } \\
\text { Proyek yang digerakkan oleh } \\
\text { batas waktu }\end{array}$ & $\begin{array}{l}\text { II } \\
\text { AKTIVITAS: } \\
\text { Pencegahan, aktivitas KP } \\
\text { Pengembangan hubungan } \\
\text { Pengenalan peluang baru } \\
\text { Perencanaan, rekreasi }\end{array}$ \\
\hline Tidak penting & $\begin{array}{l}\text { III } \\
\text { AKTIVITAS: } \\
\text { Interupsi, beberapa telepon } \\
\text { Beberapa pos dan laporan } \\
\text { Beberapa pertemuan } \\
\text { Urusan yang mendesak } \\
\text { Aktivitas yang populer }\end{array}$ & $\begin{array}{l}\text { IV } \\
\text { AKTIVITAS: } \\
\text { Hal-hal sepele, kerja sibuk } \\
\text { Beberapa pos } \\
\text { Beberapa telepon } \\
\text { Pemborosan waktu } \\
\text { Aktivitas menyenangkan }\end{array}$ \\
\hline
\end{tabular}

Gambar 1 Kuadran Penting dan Mendesak

(Sumber: Covey, 2004:151)

Kuadran I mendesak sekaligus penting. Ini adalah aktivitas "krisis” atau “masalah”. Ini adalah fokus pada masalah, mereka yang berada di sini adalah manager krisis, orang yang pikirannya berfokus pada masalah, produsen yang digerakkan oleh batas waktu. Kalau seorang fokus pada kuadran I, kuadran ini akan menjadi makin besar sehingga mendominasi diri. Ini seperti ombak yang terus menerpa. Sebuah masalah besar datang menerpa dan menyeret seorang, dan sementara ia berusaha untuk bangkit kembali, masalah besar lain sudah datang, sehingga ia terhempas dan sulit bangun lagi. Kelegaan yang sering didapatkan adalah dengan melarikan diri pada aktivitas-aktivitas yang tidak penting dan juga tidak mendesak di kuadran IV. Jadi ketika seorang fokus pada kuadran I, maka 90\% dari waktu akan tersita di situ, sementara 10\% lagi terbagi antara kuadran IV dan III. Ini satu pengaturan waktu yang sangat memberatkan diri sendiri karena hidup berdasarkan krisis.

Orang dengan manajemen pribadi yang efektif lebih fokus pada kudran II. Kuadran ini berhubungan dengan hal-hal yang tidak mendesak, namun penting. Ia berfokus pada hal-hal seperti membina hubungan, menulis pernyataan misi pribadi, perencanaan jangka panjang, latihan, pemeliharaan, pencegahan, persiapan, dsb. Peter Drucker mengemukakan bahwa orang yang efektif bukanlah orang yang pikirannya tertuju pada masalah; mereka adalah orang yang pikirannya tertuju pada peluang. Mereka memberi makan peluang dan melaparkan masalah. Mereka berpikir secara preventif (Covey, 2004). Orang-orang yang efektif juga mempunyai krisis dan keadaan darurat Kuadran I yang memerlukan perhatian langsung mereka, tetapi jumlahnya terhitung kecil. Artinya, hal-hal penting dan belum mendesak itu (Kuadran II) sudah mereka tangani sebelum berpindah ke Kuadran I. Hal penting yang mereka selalu perhatikan adalah adanya keseimbangan antara produk dan kemampuan produksi, dengan tetap fokus pada aktivitas penting, dengan menjalankan aktivitas pembangun kapasias pada Kuadran II. Adalah sebuah pengelolaan waktu yang tergolong bagus ketika kita mengalokasikan waktu kita sebanyak 60\% untuk Kuadran II, 20\% untuk Kuadran I, sisanya $15 \%$ untuk Kuadran III dan 5\% untuk Kuadrant IV. Ada juga yang berhasil menjalankan penggunaan waktu mereka 75\% untuk Kuadran II dan 15\% untuk Kuadran I, sisanya untuk Kuadran III dan IV. Ini menuntut disiplin diri tinggi, dengan hasil yang tentu jauh lebih baik.

Dengan cara penggunaan waktu seperti ini, maka efektivitas jadi meningkat secara drastis karena di sini krisis dan masalah bisa menyusut. Hal ini terjadi karena berpikir ke depan, menangani akarnya, menangani halnya sebelum menjadi krisis, mengerjakan hal-hal preventif. Dengan cara seperti ini, maka situasinya tidak berkembang menjadi krisis. Dalam jargon manajemen waktu, hal ini disebut Prinsip Pareto - 80 persen hasil diperoleh dari 20 persen aktivitas. 


\section{Memproteksi Waktu yang Sudah Ditetapkan}

Alan (dalam Adebisi, 2013) mencatat, kunci sukses time management adalah perencanaan dan proteksi atas waktu yang sudah direncanakan, yang sering mencakup pengondisian lingkungan, khususnya pengkondisian kembali harapan dari pihak-pihak lain yang terlibat. Time management adalah tentang membuat perubahan terkait dengan penggunaan waktu. Untuk memastikan keefektifan time management, seorang harus menerapkan time management system yang akan membantu untuk melihat bahwa perubahan perlu dilakukan, dalam arti bahwa tahap pertama dalam time management adalah menganalisis bagaimana ia menentukan perubahan apa yang ingin dilakukan (Susan, 2012).

Time management yang efektif tidak datang begitu saja secara alami, melainkan untuk terhindar dari bekerja mati-matian pada saat yang sudah mepet, sebaliknya dapat kesempatan besar sukses dalam bisnis, penerapan time management merupakan hal sangat penting untuk dilakukan. Pengaturan waktu yang sudah dibuat, harus diperhatikan dengan baik. Jika hal itu berkenaan dengan pengerjaan suatu proyek, setelah time management dirancang dengan baik dan ditetapkan, harus disosialisasikan dengan baik kepada pihak-pihak yang terlibat. Semua pihak yang terlibat, termasuk pimpinan proyek perlu konsisten mengikuti pengaturan waktu yang telah dibuat.

Terkait dengan pengembangan time management, baik pada level organisasi maupun level pribadi, hal yang sering menjadi masalah adalah ketidakkonsistenan mengikuti rancangan penggunaan waktu yang telah dibuat. Ada kecenderungan gampang melanggar ketetapan yang telah dibuat. Tantangan yang sering muncul adalah adanya hal-hal yang tiba-tiba muncul dan dirasa sebagai hal penting untuk segera ditangani. Ketika hal-hal tersebut muncul dengan jumlah yang terus bertambah, sementara pengendalian diri yang baik terhadapnya tidak dimiliki, maka dengan mudah perhatian, waktu, dan tenaga tersita banyak untuk itu. Dampak semuanya itu adalah kegagalan mewujudkan misi, menelantarkan tujuan penting yang ingin diraih. Untuk menghindari hal itu, perlu kembali pada perencanaan waktu yang sudah dibuat dengan baik, yang sudah ditetapkan dengan memerhatikan di dalamnya perwujudan misi pribadi, tujuan yang ingin diraih, pemenuhan harapan terkait dengan keluarga, dan pencapaian hasil yang diinginkan oleh organisasi tempat bekerja.

\section{Manfaat Time Management}

Time management yang baik sangat penting dalam menghadapi tekanan dari kehidupan modern tanpa harus mengalami banyak stres. Waktu yang bagus di pekerjaan berarti melakukan pekerjaan berkualitas tinggi, bukan terutama tinggi dalam hal kuantiti. Claessens, et al (2007) menemukan bahwa menggunakan teknik time management akan berhubungan langsung dengan kinerja dan kepuasan, serta dapat mengurangi kegalauan dan kecemasan.

Time management menghadirkan skills, tools, dan kemampuan melakukan hal yang benar pada waktu yang benar, dengan usaha minimal dan sumber daya minimal, efektif dan efisien, yang melaluinya seorang bisa mencapai tujuan dan nilai-nilai personal yang diprioritaskan. Time management membuat orang menjadi penting dan terhormat, mampu mengorganisasi hal-hal di sekitar, serta membuat seseorang mampu mengoptimalkan kinerja. Kebutuhan terhadap time management sudah makin diakui, dianggap penting bukan hanya sebagai sebuah unsur motivasi di belakang kinerja karyawan dan produktivitas, melainkan juga sebagai dasar dari semua kinerja organisasi. Dalam dunia bisnis, waktu adalah salah satu aset penting bagi apa saja dalam organisasi. Penting untuk melatih karyawan dalam hal manajemen waktu yang sistematis, sehingga mereka dapat mencapai hasil produktivitas dalam periode waktu yang sudah ditentukan.

Kinerja organisasi maksudnya adalah tempat organisasi itu dalam hubungannya dengan pesaingnya terkait dengan market share, profit dan capital base. Organisasi sedemikian dibangun melalui kontribusi positif dari karyawannya bagi keberhasilan organisasi (Adebisi, 2013). Pimpinan yang mempunyai visi, determinasi dan fokus jelas akan membangun organisasi yang memiliki kinerja 
sedemikian tinggi, yang akan memberi pelayanan efektif dan produktif kepada pelanggannya di semua waktu. Organisasi seperti itu adalah organisasi yang dipimpin oleh seorang pemimpin yang memiliki kemampuan pengelolaan waktu yang baik, yang mampu melakukan perubahan melalui efektivitas dan efisiensi pengelolaan waktu dan sumber daya yang tersedia. Di dalam organisasi sedemikian terdapat pembaharuan tentang semangat belajar menerus, mengaplikasikan strategi baru melalui penelitian dan pertumbuhan serta perkembangan, seraya memasukkan dalam pertimbangan mengenai nilai dan esensi dari waktu. Dia menetapkan goal yang smart, dan mengukur keberhasilan dan kegagalan selalu dalam kaitan dengan waktu. Hal itu menunjukkan tentang pentingnya waktu, tentang pengaruh positif dan juga negatifnya terhadap kinerja organisasi. Waktu terikat pada setiap aktivitas dari organisasi.

Demi efektifnya time management bagi kinerja organisasi, manajer dan karyawan dapat memutuskan yang mana saja tugas yang masuk dalam kategori tugas-tugas dasar/pokok, tugas penting dan tugas-tugas bernilai rendah, dengan bertanya: tugas mana yang memiliki nilai paling tinggi bagi organisasi; tugas mana yang dianggap penting manajer; atau, jika tidak semua tugas dapat diselesaikan, yang mana di antaranya yang harus diselesaikan. Ini akan memacu kemajuan pertumbuhan dan perkembangan bagi langkah organisasi dalam meraih sukses (Adebisi, 2013). Dalam time management diterima bahwa pengontrolan atas waktu merupakan mediator antara time management di satu pihak dan indikator dari kepuasan kerja, well-being, dan kinerja di pihak lain. Hal-hal yang terkandung sebagai hal yang esensial dalam time management dapat dimaknai sebagai kombinasi dari time assessment, goal setting, planning, dan aktivitas monitoring (Claessens, et al, 2007). Time management merupakan prediktor dari pengontrolan atas waktu, yang sekurangkurangnya secara parsial mengantarai hubungan antara time management dan well-being, seperti halnya juga kepuasaan kerja. Hubungan antara time management, pengontrolan yang diterima atas waktu, kinerja, dan well being sudah kelihatan dalam beberapa penelitian yang telah dilakukan (Häfner \& Stock, 2010).

\section{SIMPULAN}

Konsep mengenai time management yang dimulai pada masa revolusi industri telah menjadi gagasan modern perihal melakukan sesuatu secara efektif dan efisien. Time management adalah tindakan dan proses perencanaan serta pelaksanaan kontrol sadar atas sejumlah waktu yang akan digunakan untuk aktivitas tertentu, khususnya untuk meningkatkan efektivitas, efisiensi, dan produktivitas. Hidup di tengah-tengah lingkungan bisnis yang terus berubah, yang di dalamnya orangorang berhadapan dengan banyak tanggung jawab, adanya persaingan di berbagai bidang kehidupan, dan adanya tekanan dari berbagai arah dalam usaha meraih cita-cita menuntut keharusan untuk bisa mengelola waktu seefektif dan seefisien mungkin, dengan indikator produktivitas yang tinggi. Dari berbagai kajian yang telah dilakukan dapat tampak adanya hubungan signifikan dan positif antara praktek time management dan kinerja bisnis (Adebisi, 2013).

Untuk membuat time management yang baik, penetapan yang baik diperlukan mengenai apa saja yang penting dalam kehidupan, kehidupan keluarga, dan kehidupan organisasi. Time management yang baik mestinya berkaitan dengan pencapaian dan perwujudan misi dan tujuan penting kehidupan, keluarga, dan organisasi. Time management yang baik sangat penting dalam menghadapi berbagai tekanan kehidupan modern tanpa harus mengalami banyak stres. Time management bukan berarti seseorang harus mengerjakan banyak pekerjaan, melainkan bahwa ia fokus atas tugas utama yang ditetapkan; melakukan pekerjaan berkualitas tinggi, bukan kerja banyak.

Satu hal yang sangat menolong dalam hal mencapai efektivitas penggunaan waktu adalah dengan memerhatikan perbedaan antara hal yang sifatnya mendesak dengan yang sifatnya penting. Ada banyak hal yang dirasakan sebagai hal yang mendesak lalu diberikan waktu untuk 
menanggapinya. Sementara, hal yang sesungguhnya penting sering diabaikan, sehingga sering kali terperosok dalam waktu krisis yang membuat seseorang terus bergumul dengan makin banyak hal yang penting dan mendesak. Ia seharusnya menangani hal-hal penting sebelum hal itu menjadi hal mendesak, dan itu berarti fokus pada pembinaan hubungan, menulis pernyataan misi pribadi, perencanaan jangka panjang, latihan, pemeliharaan, pencegahan, persiapan, dsb.

\section{DAFTAR PUSTAKA}

Adebisi, J. F. (2013). Time management practices and its effect on business performance. Canadian Social Science, 9(1). Canadian Research \& Development Center of Sciences and Cultures, Montreal, Canada

Atkinson, F. (2009). Successful Time Management: Get More Out of Your Day. United Kingdom: Crimson Business.

Claessens, et al. (2007). A review of the time management literature. Personnel Review, 36(2), 255275.

Covey, S. R. (2004). The 7 Habits of Highly Effective People. New York: Free Press.

Fischer, C. (2001). Read this paper later: Procrastination with time-consistent preferences. Journal of Economic Behavior and Organization, 46(3), 249-269.

Häfner, A. \& Stock, A. (2010). Management training and perceived control of time at work. The Journal of Psychology, 144(5), 429-447.

Kasturi, S. R. \& Gransberg, D. D. (2002). Time management - a design-build builder's perspective. American Association of Cost Engineers, 44(9), 16-23.

König, et al. (2007). Time management problems and discounted utility. The Journal of Psychology, 141(3), 321-334.

Mitch. (2011). What is Management? http://www. managementguid/whatismanagement.com

Scott, W. (2002). Effective Time Management. http://www. tonyrobbins.com/products/time

Singh, D. \& Jain, S. C. (2013). Working process of time management in SAP HR module. International Journal of Management Research and Reviews, 3. Society of Scientific Research and Education (SSRE), Meerut, India.

Susan, W. (2012). A Time Management System that Really Works, http://www.sbinfocanada.about.com/cs/ timemanagement. 